\title{
Research on the Influence of Teacher's Thinking and Emotion Orientation on Student's creativity in Flipped Classroom Environment
}

\author{
Li Shuang ${ }^{1}$, Yang $\mathrm{An}^{2, *}$, Li Zhen ${ }^{3}$,Wei Likun ${ }^{4}$ \\ ${ }^{1234}$ Human Resources Department ,JinCheng College of Sichuan University ,Chengdu, China \\ *email:32437945@qq.com
}

\begin{abstract}
With the rise of Internet education, the flipped classroom has formed a boom in teaching reform. Creative education has also been the current hot issue. It studies the cultivation of students to create thinking and combine with flipped classroom teaching mode. 438 undergraduate students completed questionnaires on flipped classroom, positive and negative emotions and the students' creativity. Results indicated that flipped classroom can affect student's creativity,but the key to influencing student's creativity isn't to flip the classroom itself, but two important regulatory variables are teachers' critical thinking and positive and negative emotions. Teachers play an important role in the classroom, relate to the classroom or even teaching reform success, which is the value of the Internet can't subvert.
\end{abstract}

Keywords: flipped classroom; teacher's critical thinking ;emotion; creativity;

\section{Introduction}

Innovation is an inexhaustible motive force for a country's prosperity and a soul of national progress [1]. College students are a national innovation reserve force. Thus cultivating students' speculative ability, especially creativity, is an important part of education[2].Now at home and abroad increasingly popular teaching mode, not only breaks the traditional indoctrination teaching mode, but also allows students to master their own knowledge. Environment could be independent learning in the school, irritation, can facilitate the use of various resources in the school environment is more conducive to the development of students' creativity [3].

\section{Assumptions}

\subsection{Flipped Classroom and students' creativity}

Flipped Classroom(FCM) has become the focus of attention at home and abroad, is leading to profound changes in the educational model. The basic idea of FCM is the traditional learning process overturned, pre-class completion of knowledge to teach, the classroom to complete the internalization of knowledge[4].Zhang (2012)think the information environment is to achieve the basis of flipped teaching, students in the classroom before the use of teachers to provide video-based learning materials for independent study, and teachers and students in the classroom to interact with each other to explore the final to realize the new teaching model[5].San Jose State University is using MOOC in traditional teaching to flip the classroom, which allows students to complete MOOC as homework, while in the classroom it encourages deeper problem solving. (Jarrett, 2012)[6].Therefore, the following hypotheses are to be verified:

H1a: FCM is positively related to student's creativity.

$\mathrm{H} 1 \mathrm{~b}$ : MOOC is positively related to student's creativity.

Creativity is a series of continuous complex high-level psychological activities characterized by fluency, flexibility and uniqueness of thinking activities. the success of the new product development depends largely on the ability of the enterprise to create new ideas, that is the new product creativity[7]. Amabile think the novelty and usefulness of the new product is an important feature of creativity[8]. Creative thinking is an important aspect of creativity and the core of 
creative research. Divergent thinking is the most important feature of creative thinking and one of the main indicators of the determination of creativity, it reflects the potential is considered a direct expression of creativity. Therefore, the following hypotheses are to be verified:

$\mathrm{H} 2 \mathrm{a}$ :Product creation is one of the basis of creativity.

$\mathrm{H} 2 \mathrm{~b}$ : Program innovation is one of the basis of creativity.

$\mathrm{H} 2 \mathrm{c}$ : Creative thinking is one of the basis of creativity.

$\mathrm{H} 2 \mathrm{~d}$ :Graphic Structure is one of the basis of creativity.

\subsection{Teacher 's Critical Thinking}

Fischer defines critical thinking as a purposeful reflective judgment, it presents core cognitive skills including interpretation, analysis, evaluation, inference, clarification and self-regulation[9].The current situation of education in China are lack of critical thinking seriously. Critical thinking and creative thinking are interrelated. Sharon Bailin argues that this opposition between critical and creative thinking is false. First, critical thinking plays a key role in innovation; secondly, creative thinking is essentially breaking the rules, this view itself is questioned, and requires critical thinking as a tool for analysis[10].Paul and Elder argue that there are not only some of the inventions we do not fully understand, but also the critics that we do not fully understand. Because these two types have some kind of cross relationship, we always have a way to teach critical thinking and creative thinking at the same time [11].Therefore, the following hypotheses are to be verified:

H3a:Teachers is active, student's creativity is stronger.

$\mathrm{H} 3 \mathrm{~b}$ :Teacher's thinking conservative, student's creativity is weaker.

$\mathrm{H} 3 \mathrm{c}$ :Student's creativity is stronger with critical thinking.

\subsection{Positive and Negative Emotional}

Positive emotions on individual innovation behavior has a significant positive impact, negative emotions on individual innovation behavior has a significant negative impact[12].These have contributed to the individual's cognitive flexibility and divergent thinking, which in turn inspired the occurrence of creativity[13]. Individuals with negative emotions often use detailed,bottom-up information processing methods that focus on the current situation or problem, which is conducive to the optimization of the problem and is not conducive to divergent thinking[14]. Which will inhibit the occurrence of creativity. scholars have shown that positive emotions promote creativity,negative emotions affect creativity[15]. Positive emotional state can improve the ability of creative science to put forward the ability, different negative emotional state for the creative science put forward the different influence. Therefore, the following hypotheses :

H4a:Teachers are strict, student's creativity is weaker.

H4b:Students who have been criticized are less creative.

$\mathrm{H} 4 \mathrm{c}$ :Teachers often inspire, student's creativity is stronger.

H4d:Teachers just praise, student's creativity is stronger.

\section{Method}

438 students were tested in the classroom questionnaire. It was issued with 410 valid questionnaires. It taken to the Gilford Creative Test and based on the teacher to apply the positive and negative emotions of the test done. The variables are used Likert 5 scale, 1 said "very disagree ",5 means "very agree".

\subsection{Factor analysis}

In this paper, we use SPSS to analyze the reliability of the factors involved in the study.Combined reliability of Combination reliability analysis, $\mathrm{H} 1=.533, \mathrm{H} 3=-0.297, \mathrm{H} 4=0.142$. The factor load,H1a $=.412, \mathrm{H} 1 \mathrm{~b}=.444, \mathrm{H} 3 \mathrm{a}=.675, \mathrm{H} 3 \mathrm{~b}=-.434, \mathrm{H} 3 \mathrm{c}=.223, \mathrm{H} 4 \mathrm{a}=-.313, \mathrm{H} 4 \mathrm{~b}=-.147, \mathrm{H} 4 \mathrm{c}=.610, \mathrm{H} 4 \mathrm{~d}=.4$ 84. Within the normal range. 


\subsection{Variables analysis}

We are divided into 13 factors for the impact of creativity. The correlation analysis was performed on the four factors contained in the dependent variable. as shown Table 1. In this paper, two variables and creativity were analyzed. as shown in Table2.

Table 1 Variable Correlation Model

\begin{tabular}{|c|c|c|c|c|c|c|c|c|c|c|c|c|c|c|c|c|}
\hline & $\mathrm{H1a}$ & $\mathrm{H} 1 \mathrm{~b}$ & $\mathrm{H} 3 \mathrm{a}$ & $\mathrm{H} 3 \mathrm{~b}$ & $\mathrm{H} 3 \mathrm{c}$ & $\mathrm{H} 4 \mathrm{a}$ & $\mathrm{H} 4 \mathrm{~b}$ & $\mathrm{H} 4 \mathrm{c}$ & $\mathrm{H} 4 \mathrm{~d}$ & $\mathrm{H} 5 \mathrm{a}$ & $\mathrm{H} 5 \mathrm{~b}$ & $\mathrm{H} 5 \mathrm{c}$ & $\mathrm{H} 2 \mathrm{a}$ & $\mathrm{H} 2 \mathrm{~b}$ & $\mathrm{H} 2 \mathrm{c}$ & $\mathrm{H} 2 \mathrm{~d}$ \\
\hline H1a & 1 & & & & & & & & & & & & & & & \\
\hline $\mathrm{H} 1 \mathrm{~b}$ & .367 & 1 & & & & & & & & & & & & & & \\
\hline H3a & .217 & .236 & 1 & & & & & & & & & & & & & \\
\hline $\mathrm{H} 3 \mathrm{~b}$ & -.025 & -.035 & -.442 & 1 & & & & & & & & & & & & \\
\hline $\mathrm{H} 3 \mathrm{c}$ & .095 & .148 & .119 & .025 & 1 & & & & & & & & & & & \\
\hline $\mathrm{H} 4 \mathrm{a}$ & .009 & -.019 & -.216 & .380 & .193 & 1 & & & & & & & & & & \\
\hline $\mathrm{H} 4 \mathrm{~b}$ & .020 & .107 & -.059 & .160 & .130 & .352 & 1 & & & & & & & & & \\
\hline $\mathrm{H} 4 \mathrm{c}$ & .178 & .113 & .366 & -.226 & .080 & -.140 & -.097 & 1 & & & & & & & & \\
\hline $\mathrm{H} 4 \mathrm{~d}$ & .120 & .109 & .182 & -.073 & .095 & -.049 & -.143 & .341 & 1 & & & & & & & \\
\hline $\mathrm{H} 5 \mathrm{a}$ & .071 & .162 & .154 & -.022 & .152 & -.011 & .020 & .055 & .142 & 1 & & & & & & \\
\hline $\mathrm{H} 5 \mathrm{~b}$ & .088 & .131 & .160 & -.052 & .053 & -.039 & .037 & .163 & .172 & .298 & 1 & & & & & \\
\hline $\mathrm{H} 5 \mathrm{c}$ & .142 & .183 & .233 & -.050 & .124 & -.079 & -.007 & .275 & .186 & .284 & .481 & 1 & & & & \\
\hline $\mathrm{H} 2 \mathrm{a}$ & -.032 & -.043 & -.018 & -.059 & .107 & -.050 & .000 & .039 & .102 & .039 & .070 & .122 & 1 & & & \\
\hline $\mathrm{H} 2 \mathrm{~b}$ & .019 & .064 & .087 & -.063 & .061 & -.017 & -.009 & .138 & .013 & -.002 & .029 & .183 & .197 & 1 & & \\
\hline $\mathrm{H} 2 \mathrm{c}$ & -.093 & -.122 & -.040 & .035 & -.059 & -.017 & -.077 & .016 & .006 & .020 & .094 & .067 & .379 & .189 & 1 & \\
\hline $\mathrm{H} 2 \mathrm{~d}$ & .066 & .152 & .102 & -.041 & .028 & -.029 & .045 & .003 & .052 & .094 & .118 & .099 & .093 & .062 & .022 & 1 \\
\hline
\end{tabular}

Table2 Teacher's thinking and emotions on the impact of students' creativity

\begin{tabular}{lcccc}
\hline & Product Creativity & Program creativity & Creative thinking & Graphic structure thinking \\
\hline H3a. Teachers are active thinking & -0.154 & 0.034 & -0.048 & 0.2 \\
H3b. Teachers are conservative & -0.108 & -0.027 & 0.059 & 0.001 \\
H3c. Teacher 's Critical Thinking & 0.153 & 0.047 & -0.062 & 0.02 \\
H4a. Teachers are usually under strict pressure & -0.113 & 0.01 & 0.002 & -0.07 \\
H4b. Teacher just criticized & 0.034 & -0.005 & -0.083 & 0.086 \\
H4c.Teachers often encourage & 0.01 & 0.136 & 0.048 & -0.096 \\
H4d. Teacher just praise & 0.131 & -0.043 & -0.005 & 0.091 \\
\hline
\end{tabular}

\subsection{Results}

The FCM, can significantly enhance students' creativity. But the reliability of the teacher's thinking is negative, there are too many influencing factors in the relationship between teachers 'thinking and students' creativity. From the factor load, the teacher's thinking is conservative, the teacher's criticism and the strict degree of the three aspects of the analysis are negative, indicating that the selection of these three factors as a model of the negative impact of the validation is successful. From the results of the study in Table2, there is no significant correlation between teachers, thinking and teachers' emotions. There are positive and negative correlations between the various factors. But the relevance of the teacher's own influence is more complex or can be understood as not obvious. from the teacher's way of thinking, the teacher's positive and negative emotions on the impact of the degree of creativity of the students point of view, the teacher's thinking activity and product creativity, the influence of. And the teacher's ideological conservatism and product creation and management creativity are also the opposite effect. Teacher's factors and students' creativity in the direct impact of the relationship are not prominent, there may be something we did not take into account, such as the age of students, professional, gender, personality, hobbies, family background, school environment, class atmosphere and need further study.

\section{Discussion}

This study believes that teachers are actively under the emotional guidance of the classroom. When teachers ' positive emotions are applied, the classroom is more influential to the creativity. However, due to the complexity and variability of creativity itself and the influence of other variables, the influence of teachers' criticism is not significant, because there are too many factors that affect the 
students' creativity. Subject to subjective factors, so the result is not obvious. In this era of the Internet, teacher should first develop their own critical thinking, rational use of FCM teaching methods, and by the positive emotions to affect students, so that students more independent decision-making, teachers are not only teachers but coaches. Cultivate students' innovative thinking and students' positive psychology. Therefore, the teacher to play an important coach role in the transition to the classroom, which is the value of the Internet can't subvert.

\section{Acknowledgement}

This paper is funded by Teacher Education Research Center Project of Sichuan Province (The Key research base of philosophy and social sciences in Sichuan Province ,Project No.:TER2016-015); New School Reform and Development Research Center Project (The Key Research Base of Humanities and Social Sciences in Sichuan Province, Project No.:XJXY2016B10); Education and Research Project of Sichuan University Jincheng College: A Study on The Mooc and interactive mode with the flipped classroom in Entrepreneurship Management (2017) , The Reform of Financial Management Course by Using Creative Thinking(2016).

\section{References}

[1] NI Jia-qi, LU Yong-li, LIU Xia. The Comparison Teachers' Belief of Creative Students Cultivation between Chinese and Germany [J]. Teacher Education Research.China. May,2013.

[2] Pang MCS, Wong TKS , Ho SCJ .Changing economics and health worker training in modern China[J].The Yale-China Health Journal ,2002 , 1 :61-84.

[3] Yang An. The Empirical Research of Constructing Innovation and Entrepreneurship Education Support System Based on the Internet Era [C]. Proceedings of 2016 International Conference on Strategic Management,The CPCI-SSH Index 2017,Sichuan University Press,2016:910-917.

[4] Kathleen F.Upside Down and Inside Out: Flip Your Classroom to Improve Student Learning[J].Learning and Leading with Technology,2012(6).

[5] Zhang Yan. Turn the classroom teaching model for primary school information technology course action research [D].Capital Normal University .China,2014.

[6] Jarrett,J.(2012). What Are MOOCs and Why Are Education Leaders InterestedinThem[EB/OL]. 2013-12-16.http://www.huffingtonpost.com.

[7] Burroughs JE, Dahl D W, Moreau C Petal. Facilitating and rewarding creativity during new product development[J].Joural of Marketing.2011,75(4):53.

[8] Amablile.TM.Creativity and innovation in organizations[M].Boston:Harvard Business School,1996.

[9] Peter A.Facione.Critical Thinking: What It Is and Why ItCounts, 1992-2013,Peter A.Facione,Measured Reasons and The California Academic Press,Millbrae,CA.2013.

[10] Sharon Bailin.Critical and Creative Thinking[J].Informal Logic,Vol.IX,No.1,1987.

[11] Richard Paul \&Linda Elder.The Thinker's Guide to the Nature and Functions of Critical and Creative Thinking[M].Tomales: Foundation for Critical Thinking Press, 2008.

[12] Geng Xin. The Impact of Leadership Authorization Enforcement on Employee Innovation Behavior, Emotion and Team Innovation [D]. Shanghai Jiao Tong University, China, 2011.

[13] Davis M A. Understanding the Relationship between Mood and Creativity:A Meta-analysis[J].Organizational Behavior and Human Decision Processes,2009,108( 1):25-38.

[14] Lan Xin, Empirical Study on the Five-Dimensional Influencing Factors of Entrepreneurial Performance[C]. Proceedings of 2012 3rd International Asia Conference on Industrial Engineering and Management Innovation, The Engineering Index,2014,Vol.1035-1039.

[15] Yang An . An empirical study on the Prisoners' Dilemma of management decision Using big data[C].10th ICMSEM 2016, The Engineering Index, published by Springer Nature. 2017.551-562. 